\title{
Kajian Kelayakan Finansial Fotovoltaik Terintegrasi On Grid Dengan Kapasitas 20 kWp
}

\author{
Muchamad Nur Qosim ${ }^{1}$; Rinna Hariyat ${ }^{2}$; Isworo Pujotomo ${ }^{3}$ \\ 1, 2,3 Institut Teknologi PLN \\ ${ }^{1}$ mn_qosim@yahoo.com \\ ${ }^{1}$ m.qosim@itpln.ac.id
}

\begin{abstract}
Entering the 21 st century, oil and gas reserves are running low. While the demand for energy is increasing, especially in industrialized countries will increase to $70 \%$ between 2000 and 2030 . In 2017, the need for electricity reaches 25.4 trillion $\mathrm{kWh}$. Solar energy that can be generated for the whole of mainland Indonesia which has an area of \pm 2 million $\mathrm{km} 2$ with a radiation distribution of $4.8 \mathrm{kWh} / \mathrm{m} 2 /$ day is $5.10 \mathrm{~mW}$ or equivalent to $112,000 \mathrm{gWp}$. With the method of observation in various literature and field studies, investment costs include the cost of purchasing all components of solar power plants needed, such as the cost of purchasing solar modules and the purchase of inverters. The Internal Rate of Return (IRR) is obtained more than the interest rate, which is $27.11 \%$ and it can be concluded that the on-grid PLTS planning in the 20 KWP capacity system can be aid to be feasible.
\end{abstract}

Keyword: Solar Cell, investment, electrical Energy

\begin{abstract}
ABSTRAK
Memasuki abad 21, persediaan minyak dan gas bumi semakin menipis. Sementara kebutuhan akan energi semakin meningkat, utamanya di negara-negara industri akan meningkat sampai $70 \%$ antara tahun 2000 sampai dengan 2030. Pada tahun 2017, kebutuhan energi listrik mencapai 25,4 trilyun $k W h$. Energi surya yang dapat dibangkitkan untuk seluruh daratan Indonesia yang mempunyai luas \pm 2 juta $\mathrm{km} 2$ dengan distribusi penyinaran sebesar $4,8 \mathrm{kWh} / \mathrm{m} 2 / \mathrm{hari}$ adalah sebesar $5,10 \mathrm{~mW}$ atau setara dengan $112.000 \mathrm{gWp}$. Dengan metode observasi di berbagai literature dan studi lapangan, Biaya investasi mencakup mengenai biaya pembelian seтua komponen pembangkit listrik tenaga surya yang dibutuhkan, seperti biaya pembelian modul surya dan pembelian inverter. Diperoleh Internal Rate of Return (IRR) lebih dari tingkat suku bunga, yaitu 27,11\% dan dapat disimpulkan bahwa perencanaan PLTS on-grid di system kapasitas 20 KWP ini dapat dikatakan layak.
\end{abstract}

Kata kunci: Cel surya, investasi, Energi listrik 


\section{KILAT}

Vol. 10, No. 1, April 2021, P-ISSN 2089-1245, E-ISSN 2655-4925

DOI: https://doi.org/10.33322/kilat.v10i1.544

\section{Pendahuluan}

Energi (daya) merupakan syarat utama untuk melakukan pekerjaan atau kegiatan meliputi listrik, energi mekanik, energi elektromagnetik, energi kimia, energi nuklir dan panas, Memasuki abad 21, persediaan minyak dan gas bumi semakin menipis. Sementara kebutuhan akan energi semakin meningkat, utamanya di negara-negara industri akan meningkat sampai $70 \%$ antara tahun 2000 sampai dengan 2030. Pada tahun 2017, kebutuhan energi listrik mencapai 25,4 trilyun kWh. Namun sumber energi primer (minyak dan gas bumi) hanya mampu menyumbang 14,5 Trilyun kWh.

Energi surya merupakan energi yang potensial dikembangkan di Indonesia, mengingat Indonesia merupakan negara yang terletak di daerah khatulistiwa. Energi surya yang dapat dibangkitkan untuk seluruh daratan Indonesia yang mempunyai luas \pm 2 juta $\mathrm{km} 2$ dengan distribusi penyinaran sebesar $4,8 \mathrm{kWh} / \mathrm{m} 2 /$ hari adalah sebesar $5,10 \mathrm{~mW}$ atau setara dengan $112.000 \mathrm{gWp}$. Oleh karena itu energi surya memiliki keunggulan-keunggulan dibandingkan dengan energi fosil, diantaranya:

1. Sumber energi yang mudah didapatkan.

2. Ramah lingkungan.

3. Sesuai untuk berbagai macam kondisi geografis.

Instalasi, pengoperasian dan perawatan mudah.

\section{Metode Penelitian}

Konsep tentang Perancangan PLTS sistem On grid dengan gedung STT-PLN ini membutuhkan beberapa tahapan penyelesaian. Tahapan-tahapan penelitian yang dilakukan adalah sebagai berikut:

1. Studi Literatur, yaitu mengumpulkan data-data dari buku referensi dan jurnal-jurnal yang relevan dengan topik penelitian.

2. Identifikasi masalah, yaitu dengan merumuskan latar belakang masalah pada penelitian yang dilakukan hingga tujuan dalam melakukan penelitian ini.

3. Observasi, yaitu pengumpulan data dengan mengadakan pengamatan secara langsung pada instalasi yang sudah terpasang dengan PLTS.

Berikut ini adalah gambar dari sistem konsep atau perencanaan dari PLTS on-grid, dimana kebutuhan nya tidak membutuhkan baterai dalam perakitan nya.

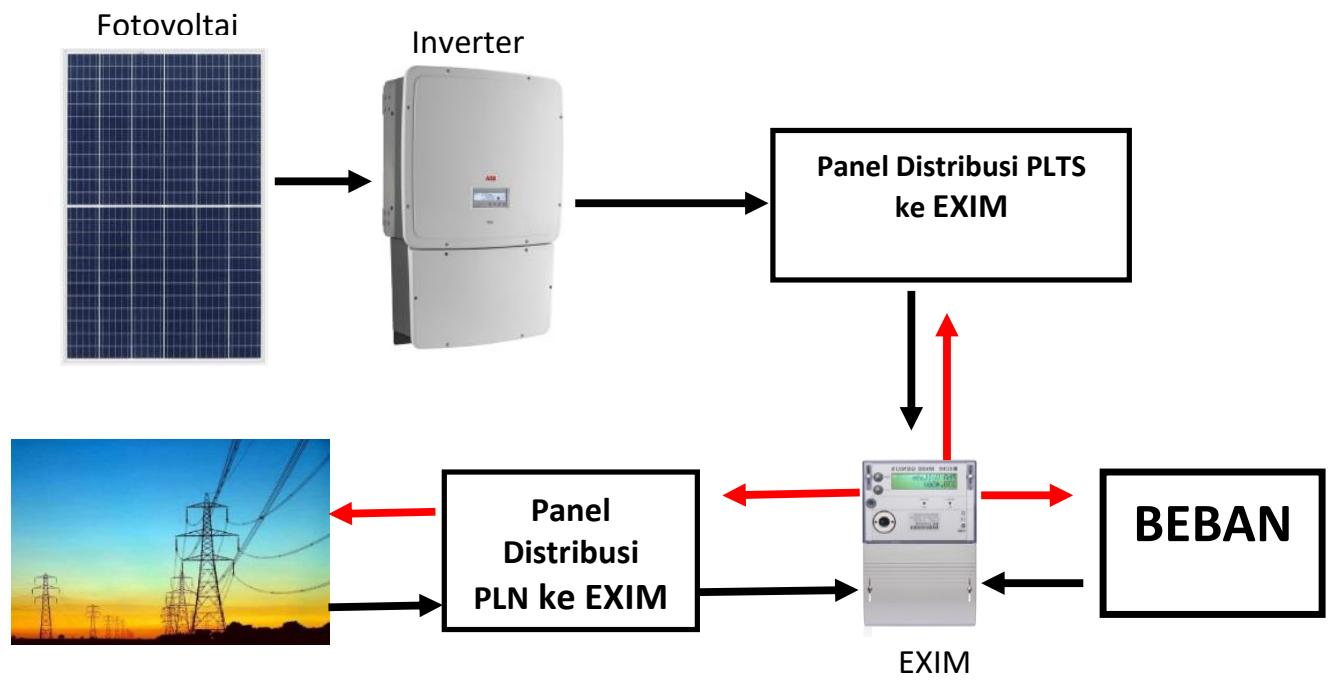

Gambar 1. Konfigurasi Sistem Konsep On-grid 
Secara singkat dijelaskan bahwa dari skema konsepnya, hasil energi yang dari PLTS akan diubah oleh inverter dari DC ke AC, yang kemudian akan di sesuaikan jalurnya oleh panel distribusi, dan dari antara panel distribusi outputanya akan masuk ke alat ukur EXIM yang akan mensinkronisasikan ke beban (konsumen) dan ke jaringan jala-jala PLN.

\section{Hasil Dan Pembahasan}

\subsection{Analisa Ekonomi}

Biaya yang pertama yang diperlukan pada tahap perencanaan yaitu biasa investasinya. Biaya investasi mencakup mengenai biaya pembelian semua komponen pembangkit listrik tenaga surya yang dibutuhkan, seperti biaya pembelian modul surya dan pembelian inverter. Di bawah ini adalah data yang peralatan yang dibutuhkan dibutuhkan beserta harganya sesuai dengan desain yang telah dibuat.

Tabel 1. Biaya investasi awal

\begin{tabular}{|c|c|c|c|c|c|c|}
\hline No. & komponen & Jumlah & Satuan & \multicolumn{2}{|c|}{ Harga } & Total (Rp) \\
\hline 1 & Panel Surya REC350 Wp & 60 & Pcs & 2.550 .000 & $/ \mathrm{pcs}$ & 153.000 .000 \\
\hline 2 & Inverter ABB $20 \mathrm{KW}$ & 1 & Pcs & 47.350 .000 & $/ \mathrm{pcs}$ & 47.350 .000 \\
\hline 3 & Mounting (rak) & 50 & Meter & 187.000 & /meter & 9.350 .000 \\
\hline 4 & Kabel & 50 & Meter & 10.000 & /meter & 500.000 \\
\hline 5 & Combainer Box & 2 & Set & 5.000 .000 & $/$ set & 10.000 .000 \\
\hline 6 & $\begin{array}{c}\text { Grounding Protection } \\
\text { Kit }\end{array}$ & 1 & Set & 5.000 .000 & /set & 5.000 .000 \\
\hline \multirow[t]{2}{*}{7} & KWh Meter Exim & 1 & Pcs & 300.000 & $/ \mathrm{pcs}$ & 300.000 \\
\hline & \multicolumn{5}{|c|}{ Total (c) } & 225.500 .000 \\
\hline
\end{tabular}

Dari tabel diatas maka dapat diketahui bahwa untuk biaya investasi yang perlukan untuk pembelian peralatan yaitu sekitar Rp. 225.500.000

\subsection{Biaya pemeliharaan dan biaya operasional (M)}

Setelah mengetahui besarnya biaya investasi yang dibutukan, maka tahap selanjutnya adalah menghitung besarnya biaya pemeliharaan dan biaya operasionalnya. Pemeliharaan PLTS terbilang cukup mudah sehingga untuk biaya pemeliharaannya juga tidak terlalu mahal. Biaya pemeliharaan dan operasional PLTS umumnya diperhitungkan sebesar 1 sampai $2 \%$ dari total biaya investasi awal (Jais, 2012). Berdasarkan acuan tersebut maka pada penelitian ini di tetapkan biaya pemeliharaan sebesar $1 \%$. penentuan ini didasari karena Indonesia hanya memiliki dua musim yaitu musim penghujan dan musim kemarau, sehingga perawatannya tidak serumit dengan negara yang memiliki 4 musim. Sehingga untuk menghitung biaya pemeliharaan dan operasional pertahun dapat dihitung dengan persamaan:

$$
\begin{aligned}
& M=1 \% \times \text { biaya investasi } \\
& M=1 \% \times 225.500 .000=\text { Rp. } 2.255 .000
\end{aligned}
$$

\subsection{Biaya siklus hidup PLTS (life cycle cost)}

Biaya siklus hidup PLTS dapat dihitung dengan menjumlahkan biaya investasi yang dibutuhkan dengan biaya pemeliharaan dan operasionalnya.

$$
\mathrm{LCC}=\mathrm{C}+\mathrm{Mpw}
$$




\section{KILAT}

Vol. 10, No. 1, April 2021, P-ISSN 2089-1245, E-ISSN 2655-4925

DOI: https://doi.org/10.33322/kilat.v10i1.544

PLTS ini diperkirakan dapat beroperasi selama 20 tahun. Untuk mengetahui berapa biaya yang harus dikeluarkan maka perlu di pertimbangkan tingkat diskonto sebesar $11 \%$. Tingkat diskonto ini mengacu pada tingkat suku bunga pada tahun 2018, sehingga besarnya biaya (present value) PLTS selama beroperasi dalam waktu 20 tahun yaitu:

$$
\begin{aligned}
& \text { Mpw }=M \frac{(1+i)^{n}-1}{i(1+i)^{\wedge} n} \\
& \text { Mpw }=2.255 .000 \frac{(1+0,11)^{20}-1}{0,11(1+0,11)^{20}} \\
& \text { Mpw }=\text { Rp. } 17.957 .304,-
\end{aligned}
$$

Sehingga biaya siklus hidup (LCC) untuk PLTS yang akan dikembangkan selama umur proyek 20 tahun diperoleh sebagai berikut:

$$
\begin{aligned}
\text { LCC } & =\mathrm{C}+\mathrm{Mpw} \\
\text { LCC } & =225.500 .000+17.957 .304 \\
& =\text { Rp. 243.457.405,- }
\end{aligned}
$$

\subsection{Menghitung Biaya Energi PLTS (Levelized Cost of Energy)}

Biaya Energi (Levelized Cost of Energy) suatu PLTS, ditentukan oleh biaya siklus hidup (LCC), faktor pemulihan modal (CRF) dan kWh produksi tahunan. Faktor pemulihan modal untuk mengkonversi semua arus kas biaya siklus hidup menjadi serangkaian biaya tahunan dihitung dengan persamaan sebagai berikut.

$$
\begin{aligned}
\mathrm{CRF} & =\frac{i(1+i)^{n}}{(1+i)^{n}-1} \\
& =\frac{0,11(1+0,11)^{20}}{(1+0,11)^{20}-1}=0,126
\end{aligned}
$$

Sedangkan produksi kWh tahunan nilainya sebesar :

Produksi $\mathrm{kWh}$ tahunan $=\mathrm{kWh}$ produksi harian $\mathrm{x} 365$

$$
\begin{aligned}
& =67,66 \mathrm{kWh} \times 365 \\
& =24,695 \mathrm{kWh}
\end{aligned}
$$

Setelah memperoleh nilai LCC, CR dan kWh produksi tahunan, maka besar biaya energy (LCoE) untuk perencanaan system PLTS ini adalah sebagai berikut :

$$
\begin{aligned}
\mathrm{LCoE} & =\frac{L C C \times C R F}{\text { Produksi } k \text { Wh tahunan }} \\
& =\frac{R p .243 .457 .405 \times 0,126}{24,695 \mathrm{kWh}} \\
& =\text { Rp. } 1.242,18 \approx \text { Rp. } 1.300-/ \mathrm{kWh}
\end{aligned}
$$

Untuk perencanaan ini akan digunakan biaya sebesar Rp. 1.300,-/kWh, Asumsi energi listrik yang terkirim ke jaringan PLN sebesar $5 \mathrm{kWh} /$ hari

$$
\begin{aligned}
\text { Harga jual ke PLN } & =5 \mathrm{kWh} / \text { hari } \mathrm{x} \text { Rp. } 1.300,- \\
& =\text { Rp. } 6.500,- \text { /hari }
\end{aligned}
$$


Jadi total harga jual yang diterima pelanggan selama 1 tahun dikurangi dengan perkiraan hari pada musim hujan selama 3 bulan, maka:

$$
\begin{aligned}
\text { Harga jual ke PLN } & =\text { Rp. } 6.500,-\mathrm{x}(365 \text { hari }-90 \text { hari }) \\
& =\text { Rp. } 1.787 .500,-
\end{aligned}
$$

\subsection{Analisis Kelayakan Investasi}

Kelayakan investasi PLTS ditentukan berdasarkan hasil perhitungan Net Present Value (NPV), Profitability Index (PI) dan Discounted Payback Period (DPP). Untuk menghitung kelayakan investasi PLTS digunakan biaya energi yaitu Rp. 1.300,-/kWh. Dengan biaya energi tersebut dan besar $\mathrm{kWh}$ produksi tahunan sebesar $24.695 \mathrm{kWh}$, maka arus kas masuk tahunannya adalah sebesar Rp. 32.103.500,-. Ditambah dengan asumsi energi listrik yang terkirim ke jaringan PLN dalam 1 tahun sebesar Rp. 1.787.500,- maka total arus masuk kas sebesar Rp. 33.891.000,-. Sedangkan pengeluaran tahunannya diperhitungkan sebesar Rp. 2.255.000,- yang ditentukan berdasarkan biaya pemeliharaan dan operasional tahunan PLTS. Tabel 4.9 menunjukkan hasil perhitungan arus kas bersih, factor diskonto (i) sebesar $11 \%$ dan nilai sekarang arus kas bersih. Faktor Diskonto (FD) :dihitung dengan persamaan sebagai berikut :

$$
\mathrm{DF}=\frac{1}{(1+i)^{n}}
$$

Misalnya perhitungan factor diskonto dengan $\mathrm{n}$ adalah tahun ke-1, maka :

$$
\begin{aligned}
\text { DF } & =\frac{1}{(1+0,11)^{1}} \\
& =0.9009
\end{aligned}
$$

\begin{tabular}{|c|c|c|c|c|c|c|c|}
\hline Th & Biaya (Rp) & $\begin{array}{c}\text { Arus Kas } \\
\text { Masuk } \\
\text { (Rp) }\end{array}$ & $\begin{array}{c}\text { Arus Kas } \\
\text { Keluar } \\
\text { (Rp) }\end{array}$ & $\begin{array}{c}\text { Arus Kas } \\
\text { Bersih } \\
\text { (NCF) } \\
\text { (Rp) }\end{array}$ & $\begin{array}{c}\text { Discoun } \\
\text { t Factor } \\
\text { (DF) } \\
11 \% \\
(\text { RP) }\end{array}$ & $\begin{array}{c}\text { Present } \\
\text { Value NCF } \\
(\text { NCF X } \\
\text { DF) }(\mathbf{R p})\end{array}$ & $\begin{array}{c}\text { Kumulatif } \\
\text { PV NCF } \\
\text { (NCF + PV } \\
\text { NCF) } \\
\text { (DF) }\end{array}$ \\
\hline- & \multirow{9}{*}{225.500 .000} & & & & 1 & & \\
\hline 1 & & 33.891 .000 & 2.255 .000 & 31.636 .000 & 0,9009 & 28.500 .872 & 28.500 .872 \\
\hline 2 & & 33.891 .000 & 2.255 .000 & 31.636 .000 & 0,8116 & 25.675 .777 & 54.176 .650 \\
\hline 3 & & 33.891 .000 & 2.255 .000 & 31.636 .000 & 0,7312 & 23.132 .243 & 77.308 .893 \\
\hline 4 & & 33.891 .000 & 2.255 .000 & 31.636 .000 & 0,6587 & 20.838 .633 & 98.147 .526 \\
\hline 5 & & 33.891 .000 & 2.255 .000 & 31.636 .000 & 0,5934 & 18.772 .802 & $\begin{array}{c}116.920 .32 \\
8\end{array}$ \\
\hline 6 & & 33.891 .000 & 2.255 .000 & 31.636 .000 & 0,5346 & 16.912 .605 & $\begin{array}{c}133.832 .93 \\
4\end{array}$ \\
\hline 7 & & 33.891 .000 & 2.255 .000 & 31.636 .000 & 0,4816 & 15.235 .897 & $\begin{array}{c}149.068 .83 \\
2\end{array}$ \\
\hline 8 & & 33.891 .000 & 2.255 .000 & 31.636 .000 & 0,4339 & 13.726 .860 & 162.795 .69 \\
\hline
\end{tabular}

Berikut merupakan table perhitungan NFC, DF dan PVNCF dengan $\mathrm{i}=11 \%$.

Table 2. Perhitungan NFC, DF dan PVNCF dengan i $=11 \%$ dengan melihat Total Produksi Energi Tahunan. 


\section{KILAT}

Vol. 10, No. 1, April 2021, P-ISSN 2089-1245, E-ISSN 2655-4925

DOI: https://doi.org/10.33322/kilat.v10i1.544

\begin{tabular}{|c|c|c|c|c|c|c|}
\hline & & & & & & 2 \\
\hline 9 & 33.891 .000 & 2.255 .000 & 31.636 .000 & 0,3909 & 12.366 .512 & $\begin{array}{c}175.162 .20 \\
4\end{array}$ \\
\hline 10 & 33.891 .000 & 2.255 .000 & 31.636 .000 & 0,3521 & 11.139 .035 & $\begin{array}{c}186.301 .24 \\
0\end{array}$ \\
\hline 11 & 33.891 .000 & 2.255 .000 & 31.636 .000 & 0,3173 & 10.038 .102 & $\begin{array}{c}196.339 .34 \\
3\end{array}$ \\
\hline 12 & 33.891 .000 & 2.255 .000 & 31.636 .000 & 0,2858 & 9.041 .568 & $\begin{array}{c}205.380 .91 \\
2\end{array}$ \\
\hline 13 & 33.891 .000 & 2.255 .000 & 31.636 .000 & 0,2575 & 8.146 .270 & $\begin{array}{c}213.527 .18 \\
2\end{array}$ \\
\hline 14 & 33.891 .000 & 2.255 .000 & 31.636 .000 & 0,2319 & 7.336 .388 & $\begin{array}{c}220.863 .57 \\
0\end{array}$ \\
\hline 15 & 33.891 .000 & 2.255 .000 & 31.636 .000 & 0,2090 & 6.611 .924 & $\begin{array}{c}227.475 .49 \\
4\end{array}$ \\
\hline 16 & 33.891 .000 & 2.255 .000 & 31.636 .000 & 0,1882 & 5.953 .895 & $\begin{array}{c}233.429 .38 \\
9\end{array}$ \\
\hline 17 & 33.891 .000 & 2.255 .000 & 31.636 .000 & 0,1696 & 5.365 .465 & $\begin{array}{c}238.794 .85 \\
5\end{array}$ \\
\hline 18 & 33.891 .000 & 2.255 .000 & 31.636 .000 & 0,1528 & 4.833 .980 & $\begin{array}{c}243.628 .83 \\
6\end{array}$ \\
\hline 19 & 33.891 .000 & 2.255 .000 & 31.636 .000 & 0,1376 & 4.353 .113 & $\begin{array}{c}247.981 .94 \\
9\end{array}$ \\
\hline 20 & 33.891 .000 & 2.255 .000 & 31.636 .000 & 0,1240 & 3.922 .864 & $\begin{array}{c}251.904 .81 \\
3\end{array}$ \\
\hline
\end{tabular}

1. Net Present Value (NPV)

Teknik Net Present Value dihitung dengan menggunakan persamaan berikut:

$$
\mathrm{NPV}=\sum_{t=1}^{n} \frac{N C F t}{(1+i)^{t}}-1 \mathrm{~A}
$$

Table 4.9 menunjukkan bahwa total nilai sekarang arus kas bersih (PV NCF) yang merupakan hasil perkalian antara arus kas bersih (NCF) dengan factor diskonto (DF) adalah sebesar $\sum_{t=1}^{n} \frac{N C F t}{(1+i)^{t}}$ adalah sebesar Rp. 227.475.494 sehingga dengan biaya investasi awal sebesar Rp. 225.500.000 maka besar nilai NPV adalah :

$$
\begin{aligned}
\mathrm{NPV} & =227.475 .494-225.500 .000 \\
& =1.975 .494
\end{aligned}
$$

Hasil perhitungan NPV yang bernilai positif sebesar Rp.1.975.494 (>0), menunjukkan bahwa investasi PLTS yang akan dikembangkan tersebut layak untuk dilaksakan.

\section{Profitability Index (PI)}

Teknik profitability Index dihitung dengan menggunakan persamaan sebagai berikut :

$$
P I=\frac{\sum_{t=1}^{n} N C F t(1+i)^{-t}}{1 A}
$$


Dengan total nilai sekarang arus kas bersih sebesar Rp. 227.475.494 dan biaya investasi awal sebesar Rp. 225.500.000 maka besar nilai PI adalah:

$$
\begin{aligned}
P I \quad & =\frac{227.475 .494}{225.500 .000} \\
& =1,009
\end{aligned}
$$

Hasil perhitungan PI yang bernilai 1,009 (>1), menunjukkan bahwa investasi PLTS yang akan dikembangkan layak untuk dilaksanakan.

\section{Discounted Payback Period (DPP)}

Discounted Payback Period (DPP) diperoleh dengan menghitung berapa tahun nilai sekarang arus kas bersih kumulatif (kumulatif PV NCF) akan sama dengan nilai investasi awal.

Table 4.9 menunjukkan bahwa pada tahun ke-14, kumulatif PV NCF mendekati nilai investasi awal dengan kekurangan sebesar Rp. 4.636.430,- yaitu dari Rp. 225.500 .000 - Rp. 220.863.570. Dalam tahun ke-15, nilai arus kas bersih (PV NCF tahun ke-15) adalah sebesar Rp. 6.203.405,- maka lama waktu yang diperlukan adalah sekitar 7 bulan (0,7 bulan dari 12 bulan) yang diperoleh dari :

$$
\frac{R p \cdot 4 \cdot 636.430}{R p \cdot 6.611 .924}=0,70
$$

Diperoleh DPP sekitar 14 tahun 7 bulan untuk menunjukkan bahwa investasi PLTS yang akan dikembangkan dengan system 20 KWP pada jangka waktu 20 tahun yang akan datang layak untuk dilaksanakan. Hal ini karena DPP yang dihasilkan menunjukkan waktu yang lebih cepat dari periode umur proyek yang ditetapkan, yaitu 20 tahun.

\section{Internal Rate of Return (IRR)}

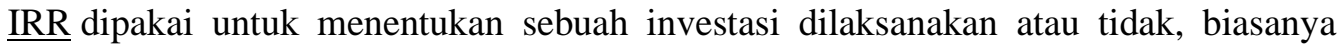
digunakan acuan kalau investasi tersebut harus lebih tinggi dari Minimum acceptable rate of return atau Minimum atractive rate of return.

Pada suku bunga IRR akan diperoleh $\mathrm{NPV}=0$, atau biasa disebut dengan IRR mengandung makna suku bunga yang dapat diberikan investasi, yang memberikan NPV $=0$. Syarat utamanya adalah apabila IRR $>$ suku bunga MARR.

IRR adalah discount rate yang membuat NPV sama dengan nol, namun tidak berhubungan dengan discount rate yang dihitung berdasarkan data di luar proyek sebagai social opportunity cost of capital (SOCC) yang berlaku umum di masyarakat (bunga deposito).

Untuk bisa memperoleh hasil akhir dari IRR kita harus mencari discount rate yang menghasilkan NPV positif, kemudian setelah itu cari discount rate yang menghasilkan NPV negatif. Digunakan persamaan berikut :

$$
\operatorname{IRR}=\mathrm{i}_{1}+\frac{N P V_{1}}{\left(N P V_{1}-N P V_{2}\right)}\left(\mathrm{i}_{2}-\mathrm{i}_{1}\right)
$$




\section{KILAT}

Vol. 10, No. 1, April 2021, P-ISSN 2089-1245, E-ISSN 2655-4925

DOI: https://doi.org/10.33322/kilat.v10i1.544

Table 3. Perhitungan IRR (Internal Rate of Return)

\begin{tabular}{|c|c|c|c|c|c|}
\hline No. & Arus kas Bersih & DF $11 \%$ & PV $11 \%$ & DF $12 \%$ & PV $12 \%$ \\
\hline 1 & 33.891 .000 & 0,9009 & 30.532 .401 & 0,8928 & 30.257 .884 \\
\hline 2 & 33.891 .000 & 0,8116 & 27.505 .935 & 0,7971 & 27.014 .516 \\
\hline 3 & 33.891 .000 & 0,7312 & 24.781 .099 & 0,7117 & 24.120 .224 \\
\hline 4 & 33.891 .000 & 0,6587 & 22.324 .001 & 0,6355 & 21.537 .730 \\
\hline 5 & 33.891 .000 & 0,5934 & 20.110 .919 & 0,5674 & 19.229 .753 \\
\hline 6 & 33.891 .000 & 0,5346 & 18.118 .128 & 0,5066 & 17.169 .180 \\
\hline 7 & 33.891 .000 & 0,4816 & 16.321 .905 & 0,4523 & 15.328 .899 \\
\hline 8 & 33.891 .000 & 0,4339 & 14.705 .304 & 0,4038 & 13.685 .185 \\
\hline 9 & 33.891 .000 & 0,3909 & 13.247 .991 & 0,3606 & 12.221 .094 \\
\hline 10 & 33.891 .000 & 0,3521 & 11.933 .021 & 0,3219 & 10.909 .512 \\
\hline 11 & 33.891 .000 & 0,3173 & 10.753 .614 & 0,2874 & 9.740 .273 \\
\hline 12 & 33.891 .000 & 0,2858 & 9.686 .047 & 0,2566 & 8.696 .430 \\
\hline 13 & 33.891 .000 & 0,2575 & 8.726 .932 & 0,2291 & 7.764 .428 \\
\hline 14 & 33.891 .000 & 0,2319 & 7.859 .322 & 0,2046 & 6.934 .098 \\
\hline 15 & 33.891 .000 & 0,2090 & 7.083.219 & 0,1826 & 6.188 .496 \\
\hline 16 & 33.891 .000 & 0,1882 & 6.378 .286 & 0,1631 & 5.527 .622 \\
\hline 17 & 33.891 .000 & 0,1696 & 5.747 .913 & 0,1456 & 4.934 .529 \\
\hline 18 & 33.891 .000 & 0,1528 & 5.178 .544 & 0,1300 & 4.405 .830 \\
\hline 19 & 33.891 .000 & 0,1376 & 4.663 .401 & 0,1161 & 3.934 .745 \\
\hline 20 & 33.891 .000 & 0,1240 & 4.202 .484 & 0,1036 & 3.511 .107 \\
\hline & Total & & 269.860 .476 & & 253.111 .544 \\
\hline \multicolumn{6}{|c|}{ IRR $=27,11 \%$} \\
\hline
\end{tabular}

Diperoleh IRR lebih dari i, yaitu 27,11\% dan dapat disimpulkan bahwa perencanaan PLTS on-grid di system kapasitas 20 KWP ini dapat dikatakan layak.

\section{Kesimpulan Dan Saran}

\subsection{Kesimpulan}

Hasil laporan ini didapat kesimpulan sebagai berikut;

1. Segi finansial secara totalitas bisa dikatakan layak untuk dioperasikan, solar panel memiliki hasil lebih dari suku bunga sebesar $27,11 \%$. 
2. Umur dan pemanfaatanya yang rendah akan biaya operasional dan polusi sangat menguntungkan bagi investor untuk membangun PLTS.

\subsection{Saran}

Adapun saran untuk lebih bisa dan digunakan dalam implementasi PLTS ini.

1. Dalam penerapan yang riil di masyarakat ternyata regulasinya masih belum banyak menguntungkan masyarakat yang akan membuat pembangkit energi terbarukan ini.

2. Bahan dan komponen semua material PLTS dan penunjang nya ini, andaikan bisa dibuat di dalam negeri sendiri akan menjadi lebih murah dan sangat bermanfaat bagi masyarakat yang akan mengimplementasikan PLTS

\section{DAFTAR PUSTAKA}

[1] Bachtiar, M. (2006). Prosedur Perencanaan Sistem Pembankit Listrik Tenaga Surya Untuk Perumahan (Solar Home System).

[2] GET STT PLN. (2017). Silabus PLTS (Edisi Pertama). Jakarta, Indonesia.

[3] Jurnal SMARTek, Vol. 4, No.3, Solarex, 1996, Discover the Newest Work Power, Frederick Court, Maryland, USA.

[4] Manan, Saiful. (2012) Energi Matahari, Sumber Energi Alternatif yang Effisiean, Handal dan Ramah Lingkungan di Indonesia. Jakarta, Indonesia.

[5] Panel Surya. (2017). Pembangkit Listrik Tenaga Surya (PLTS), panelsurya.com,

[6] S.G., Ramadhan ; Ch. Rangkuti. (2016). Perencanaan Pembangkit Listrik Tenaga Surya Di Atap Gedung Harry Hartanto Universitas Trisakti. Jakarta, Indonesia

[7] Wikipedia.org. tanggal 22 Maret 2015, Solar Cell. http://en.wikipedia.org/wiki/solar_cell.

[8] Yuwono, B. (2005). Optimasi panel sel surya dengan menggunakan sistem pelacak berbasis mikrokontroler AT89C5. Dalam B. Yuwono, Optimasi panel sel surya dengan menggunakan sistem pelacak berbasis mikrokontroler AT89C5 (hal. 11). surakarta: Budi yuwono. 